Short Communication / Kisa Bilimsel Çalışma

\title{
First record of Myxobolus muelleri (Myxosporea: Myxobolidae) in flathead grey mullet Mugil cephalus (Teleostei, Mugilidae) from Turkey
}

\author{
Şinasi UMUR*, Gökmen Zafer PEKMEZCİ, Yunus Emre BEYHAN, Ali Tümay GÜRLER, \\ Mustafa AÇICI
}

Department of Parasitology, Faculty of Veterinary Medicine, Ondokuz Mayis University, Kurupelit, Samsun, Turkey.

Summary: Myxobolus muelleri (Myxosporea: Myxobolidae), a myxosporidian parasite, was found for the first time infecting gills of flathead grey mullet (Mugil cephalus Linnaeus, 1758) from the Samsun coastal waters of Turkey. The shapes of the mature spores were regularly oval. Some spores somewhat tapered anterior end, others completely round. Spores ranged from 8.3 (7.2-9.0) $\mu \mathrm{m}$ in length, 7 (6.4-7.4) $\mu \mathrm{m}$ widths and 4.7 (4.5-4.9) $\mu \mathrm{m}$ in thickness. Two polar capsules were pyriform in shape, equal in size, 3 (2.5-3.5) $\mu \mathrm{m}$ long and $1.8(1.5-2.5) \mu \mathrm{m}$ wide. Polar capsules were usually extended half of spore cavity. There was a large intercapsular appendix between the anterior ends of the polar capsules. There were up to 6-8 sutural marking along the sutural edge. No iodinophilous vacuole discernible in the sporoplasm of the spores.

Key words: Mugil cephalus, flathead grey mullet, Myxobolus muelleri, Turkey

\section{Türkiye'de has kefalde (Teleostei, Mugilidae) ilk Myxobolus muelleri (Myxosporea: Myxobolidae) olgusu}

Özet: Samsun sahillerinde yakalanan Has kefal'in (Mugil cephalus Linnaeus, 1758) solungaçlarından ilk kez Myxobolus muelleri (Myxosporea: Myxobolidae) saptanmıştır. Ergin sporlar oval şekilde, 8.3 (7.2-9.0) $\mu \mathrm{m}$ uzunlukta, 7 (6.4-7.4) $\mu \mathrm{m}$ genişlikte ve 4.7 (4.5-4.9) $\mu \mathrm{m}$ kalınlıkta ölçülmüştür. İki polar kapsül armut şeklinde ve eşit büyüklükte olup, 3 (2.5-3.5) $\mu$ m uzunlukta ve 1.8 (1.5-2.5) $\mu \mathrm{m}$ genişliktedir. Polar kapsüller spor boşluğunun yarısını kapsamaktadır. Polar kapsüllerin ön tarafları arasında büyük kapsüler açıklık saptanmıştır. Kaynaşma (sütürel) kenarı boyunca olan sütürel çıkıntıların sayısı 6-8 adettir. Sporoplazmada fark edilebilir düzeyde iyot boyası ile boyanabilen boşluk görülmemiştir.

Anahtar sözcükler: Mugil cephalus, has kefal, Myxobolus muelleri, Türkiye.

Myxobolus Bütschli, 1882 is the largest genus which contains over 450 of the 1700 species described in the phylum within the Myxospora (Myxozoa). These parasites primarily infect fishes, but a small number of species have been found parasitizing amphibians and reptiles $(3,4,8)$. Presently, more than 2770 species assigned to 61 genera have been described from freshwater and marine fish and many of them have a disease potential (9). The structure of myxozoan spores reflects what is also found in trophic stages. It is now generally accepted that the myxozoan life cycle requires an alternation of vertebrate and invertebrate host $(8,9)$. Myxozoan taxonomy is based on the structure of the spore stages, principally on the number of shell valves, spore shape and position of the polar capsules. Over 1300 species have been described, principally on spore morphology and in some cases on tissue tropism (5). As a group, histozoic species of Myxobolus Bütschli, 1882 infect a diverse set of specific tissues that can include specifically the tegument, eyes, gills, skeleton, glands, kidneys, gonads, scale epithelium, muscle, digestive tract, and nervous system $(5,8,10)$.

Myxobolus spp. infecting different fish species have been reported in Turkey $(1,2)$. Burgu et al (1) collected and examined totally 999 fishes from different areas of Central Anatolia between the years of 1981-1984. They found $5.5 \%$ myxosporidea that of 999 fishes. Ekingen and Sar1eyyüboğlu (4) reported that Myxosoma cerebralis caused vertebral abnormalities in rainbow trout. However, there have been reports of myxosporidea in different fish species in Turkey; there has not been a report about Myxobolus muelleri in flathead grey mullet. 


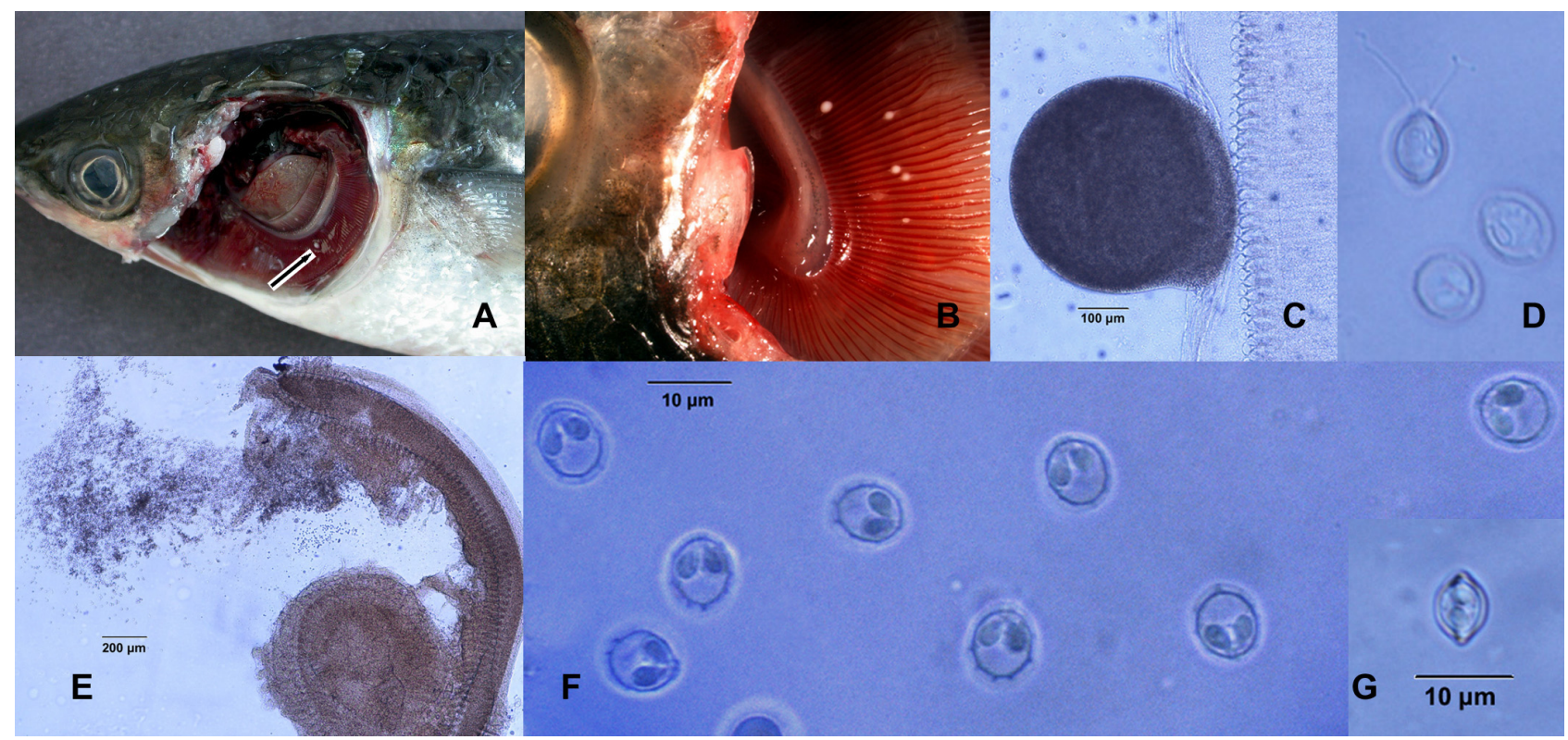

Figure 1. Fresh cysts and spores of Myxobolus muelleri.

A-B). Natural view of plasmodial cysts located in the gill filament of Mugil cephalus.

C). Micrograph of plasmodia located in gill filament of fresh wet mounts.

D). Micrograph of polar filaments of fresh wet mounts.

E). Micrograph of fresh ruptured plasmodia in gill filament.

F-G). Micrograph of fresh spores, (F) frontal and (G) sutural view.

Şekil 1. Myxobolus muelleri'nin taze kist ve sporları.

A-B). Has Kefalin solungaç filamentinde yerleşik plazmoidal kistin doğal görünümü.

C). Solungaç filamentlerinden hazırlanmış taze preparatlarda plazmoidal kistin mikroskobik görünümü.

D). Taze preparatlarda kutup iplikçiklerinin mikroskobik görünümü.

E). Solungaç filamentlerinde yeni patlamış kistin mikroskobik görünümü.

F-G). Taze sporların önden $(F)$ ve yandan $(G)$ mikroskobik görünümü.

In this paper we describe the spore morphology of Myxobolus muelleri Bütschli, 1882 for the first time in Turkey.

Freshly caught flathead grey mullets (Mugil cephalus Lin. 1758) from the Samsun coast of Black Sea region in Turkey were purchased at local fish markets on January 2009. A total of 15 fish were examined for the presence of parasites. Fish were transported to the laboratory and dissected on arrival according to a standardized protocol specifically developed for mullets (6).

Myxozoan spores morphology was identified with traditional criteria, including tissue tropism and detailed light microscopic. Descriptions of myxosporidia were made $(8,10)$ and measured according to the criteria of the literature (7). In addition to the direct observation of the above spores, photomicrographs were made by employing the technique described in agar layer method and the presence of an iodinophilic vacuole was checked by adding a drop of iodine solution to spores under a cover slip (8). Digital images of spores were taken with an oil immersion objective (Nikon Eclipse 80i, Nikon Corporation, Japan) and measured (Nikon Digital Sight DS-L1, Nikon Corporation, Japan). Spore dimensions $(\mu \mathrm{m})$ based on 20 fresh specimens.
Plasmodia were polysporic, white, round and measured up to $508.02(504.84-510.82) \times 493.56$ (490.45-495.32) $\mu \mathrm{m}$ in size were located in the gill filament (Figure 1, A-C,E). Spores were typical of the genus Myxobolus. The shapes of the mature spores were regularly oval. Some spores somewhat tapered anterior end, others completely round. There were up to 6-8 sutural marking along the sutural edge. No iodinophilous vacuole discernible in the sporoplasm of the spores. Spores ranged from 8.3 (7.2-9.0) $\mu \mathrm{m}$ in length, 7 (6.47.4) $\mu \mathrm{m}$ widths and 4.7 (4.5-4.9) $\mu \mathrm{m}$ in thickness. Two polar capsules were pyriform in shape, equal in size, 3 (2.5-3.5) $\mu \mathrm{m}$ long and $1.8(1.5-2.5) \mu \mathrm{m}$ wide. Polar capsules were usually extended half of spore cavity. There was a large intercapsular appendix between the anterior ends of the polar capsules (Figure 1, D, F, G).

\section{Taxonomic Summary}

Myxobolus muelleri Bütschli, 1882

Host: Flathead grey mullet, (Mugil cephalus Linn. 1758)

Site of infection: Gill filaments

Locality: Samsun, Black Sea Region, Turkey (41 $25^{\prime} 6^{\prime \prime}$ 'North latitude, $35^{\circ} 49^{\prime} 52^{\prime \prime}$ ' East longitude) 
Prevalence: Nine of 15 fish positive by parasitological examination.

Material deposited: Department of Parasitology, Faculty of Veterinary Medicine, Samsun, Turkey, and Protocol Collection No: 2009/1.

Most myxosporeans have strict tissue specificity with selecting definite sites for their development in the fish. The morphology and size of the myxosporean spore stage, when combined with data on host tissue specificity provide valuable information for taxonomic classification of the myxozoan parasites (3,5,7-9). Different fish species which infected with myxosporidea reported $(1,2,4)$ in Turkey. M. muelleri was reported in Black SeaUkraine (11) and we have reported M. muelleri which infected gills of flathead mullet for the first time in Black Sea-Turkey.

However having the potential of myxozoan infections in fishes because of its geographical location, there have not been done enough researches about this subject in Turkey. New approaches applied to the study of myxozoan infections in both fresh water and marine fish populations especially in Turkey need to be done with molecular techniques for their infection related and epidemiologic data.

\section{Acknowledgements}

We would like to thank V. M. Yurakhno at Institute of the Biology of the Southern Seas; National Academy of Sciences of Ukraine, for the help with identification of myxosporeans.

\section{References}

1. Burgu A, Oğuz T, Körting W, Güralp N (1988): $\dot{I}_{c}$ Anadolu'nun bazı yörelerinde tatlı su balıklarının parazitleri. Etlik Vet Mikrob Derg, 6, 143-166.

2. Doğanay A, Bozan H, Öge S (1989): Ankara'da bazı akvaryum balıklarında görülen parazitler. Ankara Üniv Vet Fak Derg, 36, 795-806.
3. Eiras JC, Molnár K, Lu YS (2005): Synopsis of the species of Myxobolus Bütschli, 1882 (Myxozoa: Myxosporea: Myxobolidae). Syst Parasitol, 61, 1-46.

4. Ekingen G, Sarıeyyüboğlu M (1980): Vertebral abnormalities in rainbow trout (S. gairdneri L.). Firat Üniv Vet Fak Derg, 1, 1-6.

5. Feist SW, Longshaw M (2006): Phylum Myxozoa. 230297. In: PTK Woo (Ed), Fish Diseases and Disorders, Protozoan and Metazoan Infections 2nd Ed, CABI Publishing, UK.

6. Kostadinova AK, Ovcharenko MO, Balbuena JA, Sarabeev VL (2004): Sampling procedures for mullet parasites. Available:

http://www.cetus.uv.es/mullpardb/SempPrD.html

Available date: 15.02.2009

7. Lom J, Arthur JR (1989): A guideline for the preparation of species descriptions in Myxosporea. J Fish Dis, 12, 151156.

8. Lom J, Dyková I (1992): Protozoan Parasites of Fishes. Elsevier Science Publishers, Amsterdam.

9. Lom J (2005): Myxozoa (Myxozoans). 41-47. In: K Rohde (Ed), Marine Parasitology, CABI Publishing, UK.

10. Shul'man, SS, Shtein, GA (1964): Myxosporidia. 56-155. In: EN Pavlovskii (Ed), Key to Parasites of Freshwater Fishes of the USSR, Israel Program for Scientific Translations, Jeruselam.

11. Yurakhno VM (1997): Myxosporeans (Protozoa: Myxosporea) from different ecological groups of Black Sea fish. Available:

http://www.ibss.iuf.net/people/yurakhno/myxospor.html Available date: 20.02.2009

Geliş tarihi: 11.03.2009 / Kabul tarihi: 08.05.2009

\author{
Adress for correspondence: \\ Dr. Şinasi Umur \\ Ondokuz Mayls Üniversitesi, Veteriner Fakültesi, \\ Parazitoloji Anabilim Dall \\ 55139 Kurupelit, Samsun /Turkiye. \\ e-mail:sumur@omu.edu.tr
}

